\title{
Mills Syndrome
}

\section{Clinical and Radiologic Asymmetry}

William Huynh, PhD, MBBS, Sicong Tu, PhD, Colin J. Mahoney, PhD, MBBS, Raymond Schwartz, PhD, MBBS, and Matthew C. Kiernan, DSc, PhD

Neurology ${ }^{\circledR}$ 2021;96:677-678. doi:10.1212/WNL.0000000000011710

Figure $13 T$ MRI Brain FLAIR
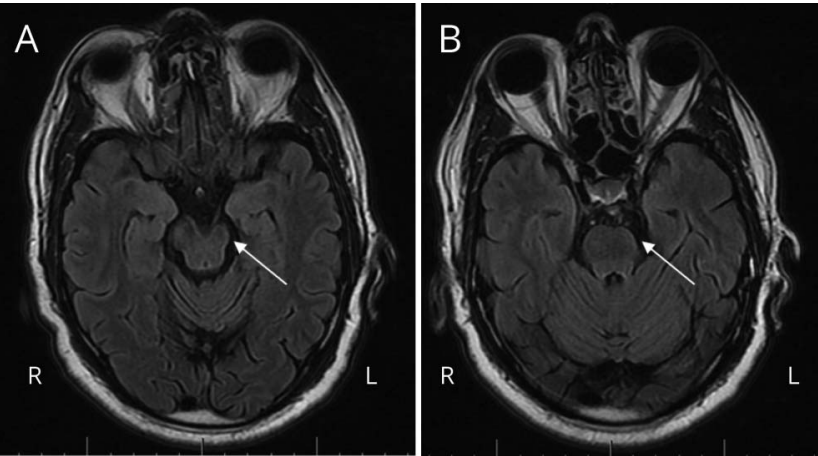

Asymmetric atrophy of the left cerebral peduncle of the midbrain (A) and pons (B).

Figure 2 3T MRI Brain Tractography

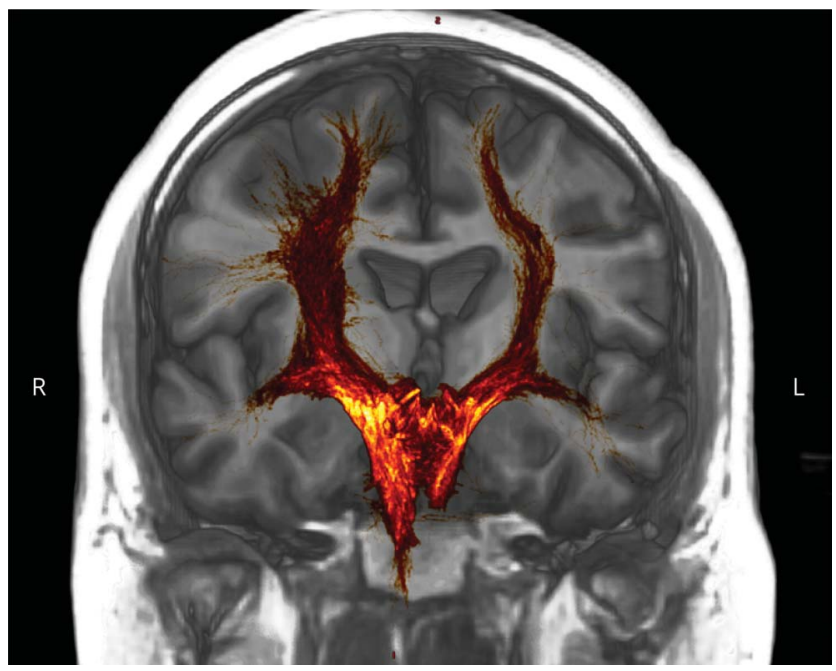

Asymmetrically reduced white matter fiber density passing through the left cerebral peduncle.

A 58-year-old man presented with a 3-year history of minimally progressive right-sided weakness. Examination revealed facial asymmetry, mild pyramidal weakness in the upper and lower limbs with spasticity, brisk reflexes, and upgoing plantar on the right only. Sensory

From the Brain and Mind Centre (W.H., S.T., C.M., M.C.K.), the University of Sydney; Prince of Wales Clinical School (W.H.), the University of New South Wales; and Southern Neurology (W.H., R.S.), Kogarah, Australia.

Go to Neurology.org/N for full disclosures. Funding information and disclosures deemed relevant by the authors, if any, are provided at the end of the article. 
examination was normal. MRI brain abnormalities are demonstrated (figures 1 and 2 and video). Serial EMG of the limbs and motor unit number estimation were symmetrically normal without evidence of concurrent lower motoneuron (LMN) pathology. Unilateral midbrain atrophy in Mills syndrome is rarely reported. ${ }^{1}$ The current case illustrates the associated asymmetric reduction in corticospinal tract fibers and absence of LMN involvement, further supporting a hemiparetic variant of primary lateral sclerosis. ${ }^{2}$

\section{Study Funding}

No targeted funding reported.

\section{Disclosure}

The authors report no disclosures relevant to the manuscript. Go to Neurology.org/N for full disclosures.

\section{Appendix Authors}

\begin{tabular}{lll}
\hline Name & Location & Contribution \\
\hline William & Brain and Mind Centre, & Designed and \\
Huynh, PhD, & University of Sydney; & conceptualized \\
MBBS & Prince of Wales Clinical & manuscript, drafted \\
& School, University of New & manuscript \\
& South Wales; Southern & \\
& Neurology, Kogarah, & \\
& Australia & \\
\hline
\end{tabular}

Appendix (continued)

\begin{tabular}{lll}
\hline Name & Location & Contribution \\
\hline $\begin{array}{l}\text { Sicong Tu, } \\
\text { PhD }\end{array}$ & $\begin{array}{l}\text { Brain and Mind Centre, } \\
\text { University of Sydney, } \\
\text { Australia }\end{array}$ & $\begin{array}{l}\text { Data acquisition and } \\
\text { interpretation, drafted } \\
\text { and final edit of the } \\
\text { manuscript }\end{array}$ \\
\hline $\begin{array}{l}\text { Colin } \\
\text { Mahoney, }\end{array}$ & $\begin{array}{l}\text { Brain and Mind Centre, } \\
\text { University of Sydney, }\end{array}$ & $\begin{array}{l}\text { Data acquisition, final edit } \\
\text { of manuscript }\end{array}$ \\
$\begin{array}{l}\text { Raymond } \\
\text { Schwartz, } \\
\text { PhD, MBBS, } \\
\text { FRACP }\end{array}$ & $\begin{array}{l}\text { Soustralia } \\
\text { Kogarah; Sydney }\end{array}$ & $\begin{array}{l}\text { Patient management, final } \\
\text { edit of manuscript }\end{array}$ \\
$\begin{array}{l}\text { Matthew } \\
\text { Kiernan, DSc, } \\
\text { PhD }\end{array}$ & $\begin{array}{l}\text { Brain and Mind } \\
\text { University of Sydney, }\end{array}$ & $\begin{array}{l}\text { Supervision and final edit } \\
\text { of the manuscript }\end{array}$ \\
\hline
\end{tabular}

\section{References}

1. Wang SP, Xu FC, Chen XW. Mills' syndrome: progressive hemiplegia with atrophy of unilateral cerebral peduncle and pontine base. Neurol Sci 2015;36: 1487-1489.

2. Gastaut JL, Bartolomei F. Mills' syndrome: ascending (or descending) progressive hemiplegia: a hemiplegic form of primary lateral sclerosis? J Neurol Neurosurg Psychiatry 1994;57:1280-1281.

\section{Get NeuroReady!}

Preparing for the neurology boards? Up for recertification? Looking for a solid foundational knowledge in neurology? Get ready with the AAN's convenient online courses-NeuroReady: Board Prep Edition or NeuroReady: Continuing Certification Edition, and the new NeuroReady: Advanced Practice Provider Edition. Includes 12 months of access. Get ready to review, self-assess, and succeed at AAN.com/NeuroReady.

\section{Announcing... Child Neurology: A Case-Based Approach Cases from the Neurology ${ }^{\circ}$ Resident \& Fellow Section}

This collaboration between the American Academy of Neurology (AAN) and the Child Neurology Society (CNS) represents a collection of reprinted cases from the past 15 years from the Neurology Resident \& Fellow Section.

An invaluable resource for both adult and pediatric neurologists and trainees! FREE download: NPub.org/cnbook 


\section{Neurology}

\section{Mills Syndrome: Clinical and Radiologic Asymmetry \\ William Huynh, Sicong Tu, Colin J. Mahoney, et al.}

Neurology 2021;96;677-678 Published Online before print February 16, 2021

DOI 10.1212/WNL.0000000000011710

This information is current as of February 16, 2021

$\begin{array}{ll}\begin{array}{l}\text { Updated Information \& } \\ \text { Services }\end{array} & \begin{array}{l}\text { including high resolution figures, can be found at: } \\ \text { http://n.neurology.org/content/96/14/677.full }\end{array} \\ \text { References } & \text { This article cites } 2 \text { articles, } 1 \text { of which you can access for free at: } \\ & \text { http://n.neurology.org/content/96/14/677.full\#ref-list-1 } \\ \text { This article, along with others on similar topics, appears in the } \\ \text { following collection(s): } \\ \text { All Clinical Neurology } \\ \text { http://n.neurology.org/cgi/collection/all_clinical_neurology } \\ \text { Amyotrophic lateral sclerosis } \\ \text { http://n.neurology.org/cgi/collection/amyotrophic_lateral_sclerosis__ Collections } \\ \text { MRI } \\ \text { http://n.neurology.org/cgi/collection/mri } \\ \\ \text { Information about reproducing this article in parts (figures,tables) or in } \\ \text { its entirety can be found online at: } \\ \text { http://www.neurology.org/about/about_the_journal\#permissions } \\ \text { Information about ordering reprints can be found online: } \\ \text { hermissions \& Licensing } \\ \text { http://n.neurology.org/subscribers/advertise }\end{array}$

Neurology ${ }^{\circledR}$ is the official journal of the American Academy of Neurology. Published continuously since 1951, it is now a weekly with 48 issues per year. Copyright @ 2021 American Academy of Neurology. All rights reserved. Print ISSN: 0028-3878. Online ISSN: 1526-632X.

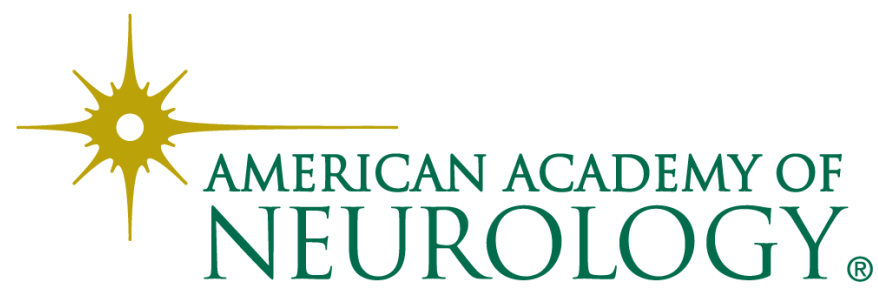

